\title{
Phenotypic Determination of Biofilm Formation and Acquired Resistance Profile of Clinically-Derived Bacterial Isolates
}

\author{
Muhammad M. Ibrahim, Abubakar Shettima, Ibrahim Y. Ngoshe, Musa Ibn Abbas, Hauwa S. Bello, \\ Askira M. Umoru, and Isyaka M. Tom
}

\section{ABSTRACT}

\begin{abstract}
Infections caused by biofilm forming bacteria is of major public health concern because of its association with multi-resistance to antimicrobial drugs and host defenses, leading to chronic and recurrent infections. Here, using Congo red agar method, Kirby-bauer disk diffusion technique and the consensus criteria of the European Centre for Disease Control (ECDC) and Centre for Disease Control (CDC), we determined the acquired resistance profile of biofilm producing phenotypes of clinically derived bacteria, classified as Multidrug resistant (MDR), extensively drug resistant (XDR) and Pandrug resistant (PDR). Fifty (50) de-identified bacterial isolates, comprising of five different species (Staphylococcus aureus, Escherichia coli, Proteus spp, Klebsiella pneumoniae and Pseudomonas aeruginosa) were sampled for this study. $\mathbf{6 4 . 0 \%}$ of these isolates were observed to produce biofilms. Isolates recovered from urine samples $(\mathbf{5 0 . 0 \%})$ were the most significant biofilm producers, chief among which was Staphylococcus aureus (15.6\%) $\left(X^{2}=0.52 ; p<.05 ; P=0.9714\right) .78 .0 \%$ of the biofilm producing phenotypes were atleast multidrug resistant $(31.4 \%$ MDR; $31.4 \%$ XDR; $15.7 \%$ PDR $)(f=0.40678 ; \mathrm{df}=3 ; \mathrm{p}<.05 ; \mathrm{P}=\mathbf{0 . 7 5 0 2})$. Extreme forms of acquired resistance (XDR and PDR) were more common among biofilm producing strains than the non-biofilm producing strains and was statistically significant $(f=5.0 ; \mathrm{p}=.026336 ; \mathrm{df}=14 ; \mathrm{p}<.05)$. All Staphylococcus aureus and Pseudomonas aeruginosa isolates were atleast multidrug resistant, with the biofilm producing strains of the latter being completely resistant to Gentamicin and Ciprofloxacin. As such, it can be deduced that resistance to multiple antimicrobial drugs is more pronounced among biofilm producing phenotypes of clinically derived bacterial isolates.
\end{abstract}

Keywords: Antimicrobial resistance, Biofilm, Clinical Bacteria, Multidrug resistance.

\section{INTRODUCTION}

Microbial biofilm is an accretion of bacterial cells enclosed in a matrix of extracellular polymeric substances (EPS) produced by bacterial cells and are attached to biotic or abiotic surfaces. A phenomenon pervasive among a diverse spectrum of bacteria, biofilm formation can be thought of as a survival strategy devised against hostile tendencies and an effective means of dispersal/settlement in a particular niche. It puts into question the notion that pathogens are evenly distributed (planktonic mode of growth) during an infectious disease episode and therefore, evenly susceptible to the antagonistic effects of the host immune response and antibiotics. The opposite has been observed to be the case as bacterial pathogens growing in the form of biofilms are restricted to a surface or exist as an infectious embolus with a highly reduced susceptibility to antibiotics, and the effects of the host immune response [1].

A plethora of infectious diseases (80\% of infectious diseases in human) have been linked to biofilm aetiology, with device-related infections being the earliest [2]. Devices
Published Online: July 25, 2020

ISSN: 2684-5199

DOI :10.24018/ejbio.2020.1.4.51

Muhammad M. Ibrahim*

University of Maiduguri, Nigeria.

(e-mail: mnistyle@yahoo.com)

Abubakar Shettima

University of Maiduguri, Nigeria.

(e-mail: shettima400@yahoo.com)

Ibrahim Y. Ngoshe

University of Maiduguri, Nigeria.

(e-mail:ibrahimngoshe30@gmail.com)

Musa Ibn Abbas

University of Maiduguri, Nigeria.

(e-mail: musaibnabbas ${ }^{\circledR}$ yahoo.com)

Hauwa S. Bello

University of Maiduguri, Nigeria.

(e-mail: hauwasbello@yahoo.com)

Askira M. Umoru

University of Maiduguri, Nigeria.

(e-mail:mohammedaskirau@gmail.com)

Tom M. Isyaka

University of Maiduguri, Nigeria.

(e-mail: isyakatom77@gmail.com)

*Corresponding Author such as intravenous catheters, prosthetic heart valves, and endotracheal tubes come with an inherent risk of surface associated infections and the adhesion of bacterial cells to the surface of these devices is aided, to certain extent, by host inflammatory molecules [1]. Bacteria frequently associated with device-related infections include Staphylococcus epidermidis, Staphylococcus aureus, Pseudomonas aeruginosa [1], Enterococcus faecalis, Streptococcus viridans, Klebsiella pneumoniae and Proteus mirabilis [3]. Pseudomonas aeruginosa has been observed to grow within the lungs of Cystic Fibrosis patients [4], [5] where they form clusters of cells enclosed in a dense matrix [6], [7].

Biofilm producing bacteria have been shown to be resistant to multiple antimicrobial drugs [8]. Such extensive resistance has been attributed to factors such as the protective covering afforded by the EPS matrix [9], reduced growth rate due to nutrient limitation within the biofilm matrix [10], embolus size [11], presence of MDR efflux pumps [12], persister cells [13], acquired resistance [14] or the combination of two or more of these factors. The aim here is to investigate the pervasiveness of acquired drug resistance among biofilm 
producing clinical bacterial isolates. This experiment is also geared towards uncovering the difference or otherwise, in resistance rate between biofilm producing and biofilm nonproducing clinical bacterial isolates.

\section{MAterials AND Methods}

\section{A. Study Area}

This is a cross-sectional qualitative study that was conducted at the laboratory of the Department of Microbiology, University of Maiduguri, Northeastern Nigeria.

\section{B. Collection and Characterization of Bacterial Isolates}

Fifty (50) de-identified clinical bacterial isolates comprising of Staphylococcus aureus (10), Klebsiella pneumoniae (10), Proteus spp (10), Escherichia coli (10), and Pseudomonas aeruginosa (10) (isolated from Urine, Swab and Sputum) were randomly collected onto nutrient agar slants in Cryovials, from the laboratory of the Department of Medical Microbiology, University of Maiduguri Teaching Hospital and transferred to the laboratory of the Department of Microbiology, University of Maiduguri, where they were sub-cultured and confirmed using standard microbiological procedure [15].

\section{Biofilm Formation Test}

Detection of biofilm was done according to the method described by [16]. It is a qualitative method for the detection of biofilm production using Congo Red Agar (CRA). CRA is prepared by adding Congo red stain to an autoclaved brain heart infusion agar with sucrose at $55^{\circ} \mathrm{C}$. It is poured into culture plates and allowed to cool. It is then inoculated with the test organism and incubated at $37^{\circ} \mathrm{C}$ for $18-24$ hours aerobically. The plates were examined for the production of black colonies which is indicative of biofilm formation.

\section{Antibiotic Susceptibility Test}

Antibiotic susceptibility test was done using the Kirby Bauer disc diffusion method according to the recommendations of the Clinical Laboratory Standard Institute [17]. Each disc is impregnated with a particular antibiotic of defined concentration. Isolates were streaked onto Mueller Hinton agar plates and the antibiotic-infiltrated discs were aseptically placed on it. It is then incubated at $37^{\circ} \mathrm{C}$ for 18-24 hours. The diameter of the zones of inhibition were measured to the nearest millimeter. Based on the zone sizes, isolates were designated as either sensitive or resistant in accordance with the interpretation chart as provided by the Clinical Laboratory Standard Institute [17]. The bacterial isolates were tested against the following commonly prescribed antimicrobial drugs: SulphamethoxazoleTrimethoprim (SXT:30 $\mu$ g), Chloramphenicol (CHL:30 $\mu \mathrm{g}$ ),

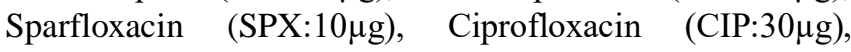
Amoxicillin (AMX:30 $\mu$ g), Amoxiclav (AMC:30 $\mu \mathrm{g}$ ), Gentamicin (GEN:10 $\mu \mathrm{g})$, Peflacin (PEF:30 $\mu \mathrm{g})$, Ofloxacin

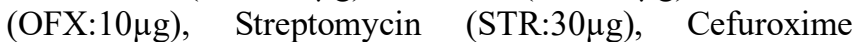

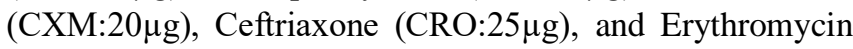

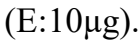

\section{E. Determination of Acquired Resistance Profile of Bacterial Isolates}

This was determined according to the criteria jointly recommended by the European Centre for Disease Control (ECDC) and Centre for Disease Control (CDC) and they are as follows:

i. Multi-Drug resistance (MDR): Non-susceptibility to atleast one antimicrobial agent in three or more antimicrobial categories.

ii. Extensively Drug-resistance (XDR): Nonsusceptibility to atleast one antimicrobial agent in all but two or fewer antimicrobial categories (bacterial isolates remain susceptible to only one or two categories).

iii. Pandrug-resistance (PDR): Non-susceptibility to all antimicrobial agents in all antimicrobial categories [18].

\section{F. Data Analysis}

Data were collected and grouped into frequencies and percentages, and presented in the form of tables and figures. Chi-square test of association and One-way ANOVA were used to determine the relationship between variables at $95 \%$ $(\mathrm{p}<.05)$ level of significance.

\section{RESULTS}

Out of 50 clinical bacterial isolates examined, 64\% (32/50) tested positive to biofilm formation test. $40(80.0 \%)$ were found to be resistant to at least three (3) or more antimicrobial drugs tested. Of this, 22 (44.0\%) were MDR, 11 (22.0\%) were XDR while $7(14.0 \%)$ were PDR. Difference in acquired resistance among isolates was statistically significant $\left(\mathrm{X}^{2}=\right.$ 12.3409; $\mathrm{P}=0.00209 ; \mathrm{p}<.05$ ) (Fig. 1).

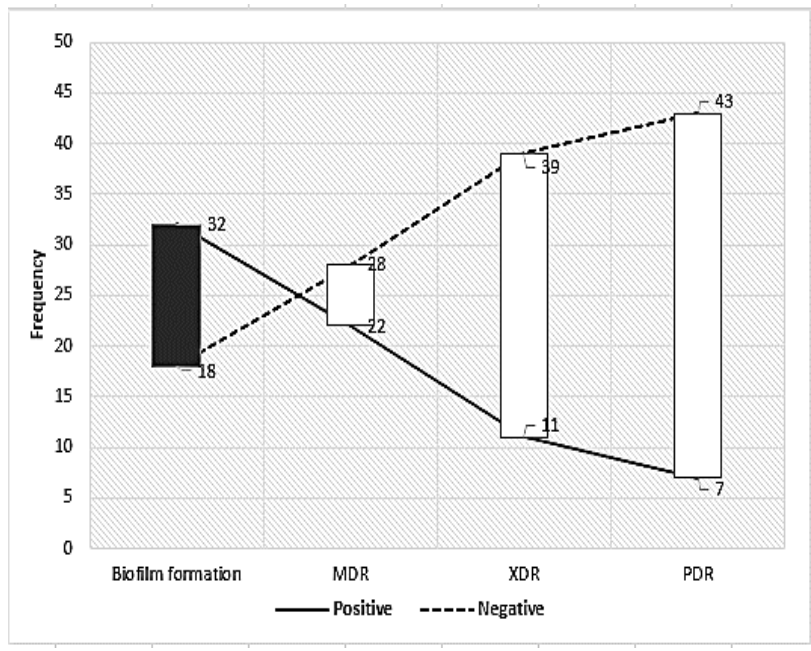

Fig. 1. Biofilm formation and acquired resistance among isolates examined.

Escherichia coli and Staphylococcus aureus recorded the highest biofilm formation rate (14.0\% respectively). Association between sample type and bacteria isolated in relation to biofilm formation revealed that Staphylococcus aureus was the most significant biofilm producer identified from urine samples (10.0\%); Klebsiella pneumoniae, Proteus spp, and Staphylococcus aureus were the most significant biofilm producer identified from swab samples $(4.0 \%$ respectively), whereas Escherichia coli was the most 
significant biofilm producer identified from sputum samples $(8.0 \%)$ (Table I).

In total, isolates identified from Urine samples yielded the highest percentage of biofilm-producing strains (32.0\%) while those identified from Swab samples recorded the least (14.0\%) (Table II).

\section{TABLE I: BIOFILM FORMATION IN RELATION TO DIFFERENCE IN SAMPLE OF ORIGIN AND BACTERIAL SPECIE ISOLATED}

\begin{tabular}{|c|c|c|c|c|c|c|}
\hline \multirow{2}{*}{ Bacterial spp } & \multirow{2}{*}{$\begin{array}{l}\text { Sample of } \\
\text { Origin }\end{array}$} & \multicolumn{2}{|c|}{ Biofilm Formation Test } & \multirow{2}{*}{ Total $(\%)$} & \multirow{2}{*}{\multicolumn{2}{|c|}{$\mathrm{X}^{2} / p$-value }} \\
\hline & & Positive (\%) & Negative (\%) & & & \\
\hline \multirow{3}{*}{ Staphylococcus aureus } & Urine & $5(10.0)$ & $1(2.0)$ & $6(12.0)$ & \multirow{3}{*}{$\begin{array}{l}1.2698 / 0 \\
.2598\end{array}$} & \multirow{15}{*}{$\begin{array}{l}0.5208 / 0 \\
.9714\end{array}$} \\
\hline & Swab & $2(4.0)$ & $2(4.0)$ & $4(8.0)$ & & \\
\hline & Sputum & $0(0.0)$ & $0(0.0)$ & $0(0.0)$ & & \\
\hline \multirow{3}{*}{ Klebsiella pneumoniae } & Urine & $1(2.0)$ & $1(2.0)$ & $2(4.0)$ & \multirow{3}{*}{$\begin{array}{l}0.6250 / 0 \\
.7316\end{array}$} & \\
\hline & Swab & $2(4.0)$ & $2(4.0)$ & $4(8.0)$ & & \\
\hline & Sputum & $3(6.0)$ & $1(2.0)$ & $4(8.0)$ & & \\
\hline \multirow{3}{*}{$\begin{array}{c}\text { Escherichia } \\
\text { Coli }\end{array}$} & Urine & $3(6.0)$ & $2(4.0)$ & $5(10.0)$ & \multirow{3}{*}{$\begin{array}{l}0.4762 / 0 \\
.4902\end{array}$} & \\
\hline & Swab & $0(0.0)$ & $0(0.0)$ & $0(0.0)$ & & \\
\hline & Sputum & $4(8.0)$ & $1(2.0)$ & $5(10.0)$ & & \\
\hline \multirow{3}{*}{ Pseudomonas aeruginosa } & Urine & $3(6.0)$ & $1(2.0)$ & $4(8.0)$ & \multirow{3}{*}{$\begin{array}{l}2.1942 / 0 \\
.3338\end{array}$} & \\
\hline & Swab & $1(2.0)$ & $3(6.0)$ & $4(8.0)$ & & \\
\hline & Sputum & $2(4.0)$ & $0(0.0)$ & $2(4.0)$ & & \\
\hline \multirow{3}{*}{$\begin{array}{l}\text { Proteus } \\
\text { Spp }\end{array}$} & Urine & $4(8.0)$ & $3(6.0)$ & $7(14.0)$ & \multirow{3}{*}{$\begin{array}{l}0.0794 / 0 \\
.7781\end{array}$} & \\
\hline & Swab & $2(4.0)$ & $1(2.0)$ & $3(6.0)$ & & \\
\hline & Sputum & $0(0.0)$ & $0(0.0)$ & $0(0.0)$ & & \\
\hline Total $(\%)$ & - & $32(64.0)$ & $18(36.0)$ & $50(100)$ & - & - \\
\hline
\end{tabular}

$\mathrm{X}^{2}=0.5208 ; p<.05$

TABLE II: BIOFILM FORMATION BASED ON SAMPLE TYPE FROM WHICH ISOLATES WERE IDENTIFIED

\begin{tabular}{|c|c|c|c|c|}
\hline \multirow{2}{*}{ Biofilm Formation Test } & \multicolumn{3}{|c|}{ Sample } & \multirow{2}{*}{ Total $(\%)$} \\
\hline & Urine $(\%)$ & Swab (\%) & Sputum $(\%)$ & \\
\hline Positive & $16(32.0)$ & $7(14.0)$ & $9(18.0)$ & $32(64.0)$ \\
\hline Negative & $8(16.0)$ & $8(16.0)$ & $2(4.0)$ & $18(36.0)$ \\
\hline Total (\%) & $24(48.0)$ & $15(30.0)$ & $11(22.0)$ & $50(100)$ \\
\hline
\end{tabular}

Table III shows the comparative acquired resistance profile of biofilm-producing and non-biofilm producing isolates. $80.0 \%$ of the isolates were at least multidrug resistant. It was observed that acquired resistance was more pronounced among biofilm producing isolates compared to non-biofilm producing isolates. Multidrug resistance was most significant among non-biofilm producers $(24.0 \%)$ than biofilm producers $(20.0 \%)$. Extensively-Drug resistance and Pandrug resistance were more pronounced among biofilm-producing isolates (20.0\% and $10.0 \%$ respectively) than the non-biofilm producers $(2.0 \%$ and $4.0 \%$ respectively). Relationship between biofilm formation and multiple drug resistance among isolates was statistically significant $(f=5.0 ; \mathrm{p}=$ $.026336 ; \mathrm{p}>.05)$.

Furthermore, biofilm-producing strains of Staphylococcus aureus and Pseudomonas aeruginosa were predominantly XDR $(8.0 \%$ and $10.0 \%$ respectively), biofilm producing strains of Escherichia coli were predominantly PDR, and that of $K$. pneumoniae and Proteus spp were mostly MDR respectively. 
TABLE III: ACQUIRED RESISTANCE PROFILE OF BIOFILM PRODUCING AND NON-BIOFILM PRODUCING CLINICAL BACTERIAL ISOLATES EXAMINED

\begin{tabular}{|c|c|c|c|c|c|c|c|}
\hline \multirow{3}{*}{ Bacterial isolates } & \multicolumn{6}{|c|}{ Biofilm formation/Acquired Resistance } & \multirow{3}{*}{ Total $(\%)$} \\
\hline & \multicolumn{3}{|c|}{ Biofilm producing $(\%)$} & \multicolumn{3}{|c|}{ Non-biofilm producing (\%) } & \\
\hline & MDR & XDR & PDR & MDR & XDR & PDR & \\
\hline $\begin{array}{l}\text { Staphylococcus } \\
\text { aureus }\end{array}$ & $3(6.0)$ & $4(8.0)$ & $0(0.0)$ & $3(6.0)$ & $0(0.0)$ & $0(0.0)$ & $10(20.0)$ \\
\hline $\begin{array}{l}\text { Klebsiella } \\
\text { pneumoniae }\end{array}$ & $3(6.0)$ & $0(0.0)$ & $0(0.0)$ & $4(8.0)$ & $0(0.0)$ & $0(0.0)$ & $7(14.0)$ \\
\hline Escherichia coli & $0(0.0)$ & $1(2.0)$ & $3(6.0)$ & $0(0.0)$ & $1(2.0)$ & $1(2.0)$ & $6(12.0)$ \\
\hline $\begin{array}{l}\text { Pseudomonas } \\
\text { aeruginosa }\end{array}$ & $1(2.0)$ & $5(10.0)$ & $0(0.0)$ & $4(8.0)$ & $0(0.0)$ & $0(0.0)$ & $10(20.0)$ \\
\hline Proteus spp & $3(6.0)$ & $0(0.0)$ & $2(4.0)$ & $1(2.0)$ & $0(0.0)$ & $1(2.0)$ & $7(14.0)$ \\
\hline Total $(\%)$ & $10(20.0)$ & $10(20.0)$ & $5(10.0)$ & $12(24.0)$ & $1(2.0)$ & $2(4.0)$ & $40(80.0)$ \\
\hline
\end{tabular}

$f=5.0 ; \mathrm{p}=.026336 ; \mathrm{p}>.05 ;$ *significant

Overall resistance pattern of isolates against the antimicrobial drugs tested has shown that the highest resistance rate was against Gentamicin and Streptomycin. Staphylococcus aureus were highly resistant to STR and CIP, $K$. pneumoniae were resistant against GEN, SXT, AMP, OFX; E. coli were resistant against GEN, STR, SXT, PEF, OFX; $P$. aeruginosa were resistant against GEN, STR, CIP, SPX, CHL; and Proteus spp were resistant against GEN, PEF, AMC, CHL (Fig. 2).

Acquired resistance profile of biofilm-producing isolates has shown that $31.25 \%$ were MDR and XDR respectively, while $15.625 \%$ were PDR (Table IV).

Resistivity pattern of biofilm-producing isolates has shown that Staphylococcus aureus were observed to be highly resistant to Ciprofloxacin (85.7\%), Klebsiella pneumoniae were highly resistant to Ofloxacin and Sparfloxacin (83.3\% respectively), Escherichia coli were completely resistant to Ofloxacin (100\%), Pseudomonas aeruginosa were completely resistant to Gentamicin, Streptomycin, Ciprofloxacin and Chloramphenicol (100\%), and Proteus spp were highly resistant to Amoxiclav, Gentamicin, Pefloxacin, Ofloxacin, Chloramphenicol and Sparfloxacin (83.3\% respectively) (Table V).

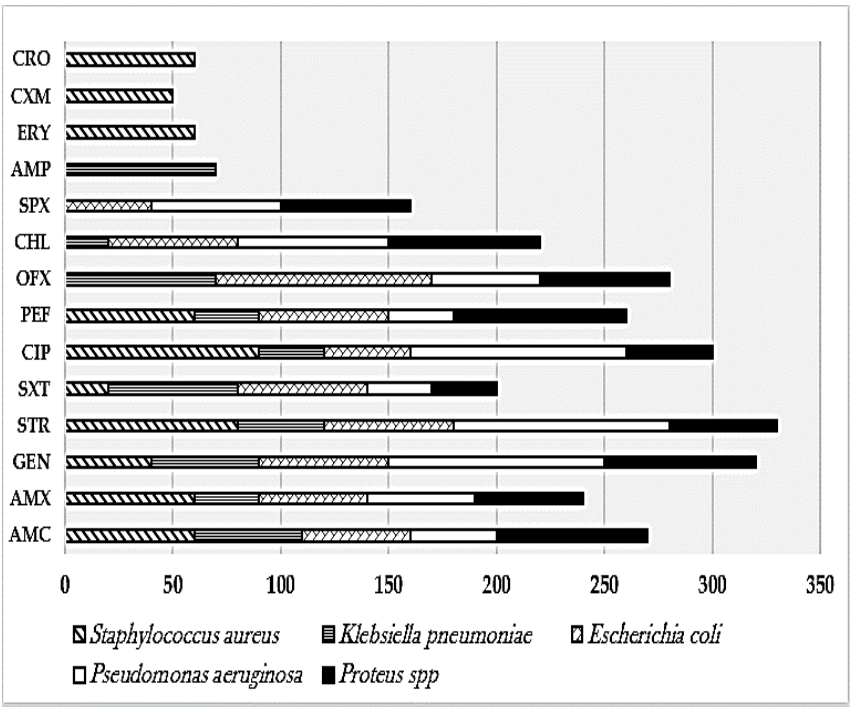

Fig. 2. Resistivity profile of the clinical bacterial isolates examined. Isolates were highly resistant to Streptomycin and Gentamicin. S. aureus isolates were highly resistant to GEN and CIP, and so were Pseudomonas aeruginosa isolates.

TABLE IV: ACQUIRED RESISTANCE PROFILE OF BIOFILM PRODUCING BACTERIAL SPECIE EXAMINED

\begin{tabular}{|c|c|c|c|c|c|}
\hline \multirow{2}{*}{$\begin{array}{l}\text { Biofilm producing } \\
\text { bacterial spp }\end{array}$} & \multicolumn{4}{|c|}{ Acquired resistance profile (\%) } & \multirow{2}{*}{ Total $(\%)$} \\
\hline & MDR & XDR & PDR & None & \\
\hline Staph. aureus & $3(9.375)$ & $4(12.50)$ & $0(0.000)$ & $0(0.000)$ & $7(21.875)$ \\
\hline K. pneumoniae & $3(9.375)$ & $0(0.000)$ & $0(0.000)$ & $3(9.375)$ & $6(18.750)$ \\
\hline E. coli & $0(0.000)$ & $1(3.125)$ & $3(9.375)$ & $3(9.375)$ & $7(21.875)$ \\
\hline P. aeruginosa & $1(3.125)$ & $5(15.625)$ & $0(0.000)$ & $0(0.000)$ & $6(18.750)$ \\
\hline Proteus spp & $3(9.375)$ & $0(0.000)$ & $2(6.250)$ & $1(3.125)$ & $6(18.750)$ \\
\hline Total $(\%)$ & $10(31.250)$ & $10(31.250)$ & $5(15.625)$ & $7(21.875)$ & $32(100)$ \\
\hline
\end{tabular}

$f=0.40678 ; \mathrm{df}=3 ; p<.05 ; \mathrm{P}=0.7502$ 
TABLE V: PERCENTAGE RESISTANCE RATE OF BIOFILM PRODUCING CLINICAL BACTERIAL SPECIE EXAMINED

\begin{tabular}{cccccc}
\hline \multirow{2}{*}{$\begin{array}{c}\text { Antimicrobial } \\
\text { Drugs Tested }\end{array}$} & \multicolumn{5}{c}{ Biofilm producing clinical bacterial isolates } \\
\cline { 2 - 6 } & Staph aureus $(\%)$ & $\begin{array}{c}\text { Klebsiella } \\
\text { pneumoniae }(\%)\end{array}$ & E. coli $(\%)$ & $\begin{array}{c}\text { Pseudomonas } \\
\text { aeruginosa }(\%)\end{array}$ & Proteus spp (\%) \\
\hline AMC & 57.1 & 66.7 & 57.1 & 16.7 & 83.3 \\
AMX & 71.4 & 66.7 & 57.1 & 50.0 & 66.7 \\
GEN & 42.9 & 28.6 & 57.1 & 100 & 83.3 \\
STR & 71.4 & 16.7 & 57.1 & 100 & 66.7 \\
SXT & 28.6 & 28.6 & 57.1 & 50.0 & 28.6 \\
CIP & 85.7 & 16.7 & 42.9 & 100 & 50.0 \\
PEF & 57.1 & 28.6 & 57.1 & 16.7 & 83.3 \\
OFX & - & 83.3 & 100 & 50.0 & 83.3 \\
CHL & - & 16.7 & 57.1 & 100 & 83.3 \\
SPX & - & 83.3 & 42.9 & 50.0 & - \\
ERY & 71.4 & - & - & - & - \\
CXM & 57.1 & - & - & - & - \\
CRO & 71.4 & - & - & - \\
\hline
\end{tabular}

\section{Discussion}

Antimicrobial resistance renders antibiotics that were once a breakthrough in the treatment of infectious diseases, ineffective and diseases that were once treatable have become difficult to treat. More so, clinical bacterial isolates have now developed the capacity to become resistant to multiple antibiotics of different classes. In this study, four-fifth of the clinical bacterial isolates examined were resistant to at least three antimicrobial drugs of different classes, giving rise to typical multidrug resistant strains. A similar pattern was observed by [19] in a research conducted in Ethiopia. While trying to look at the possible cause of multiple resistance, they found out that more than $50 \%$ of the gram-negative bacteria isolated harboured extended-spectrum beta-lactamases (ESBL) and/or AmpC.

A significant majority of clinical bacterial isolates examined in this study have been found to produce biofilms. It was observed to be more common among Staphylococcus aureus and Pseudomonas aeruginosa isolates. This is similar to the reports of [20]. They concluded that biofilm formation is a heterogeneous property amongst clinical strains and is associated with bacterial specie and certain clonal types.

Staphylococcus aureus biofilm is a multilayered biofilm embedded within a glycocalyx or slime layer of the glycocalyx as primarily composed of teichoic acids and Staphylococcal host proteins [21]. Staphylococcal infections that have demonstrated a biofilm component include Osteomyelitis (where S. aureus attaches to localized areas of trauma on the bone and divides by binary fission to form an early biofilm) [22], chronic wound infections such as diabetic foot ulcers, venous stasis ulcers and pressure sores [23] and polymicrobial biofilm infections, an example include $S$. aureus favorably binding to the hyphal form of $C$. albicans and develop biofilm [24].

It was also observed in this study, that isolates recovered from Urine samples exhibited the highest biofilm formation rate. This is an important finding in the understanding that biofilm formation has been associated with specific clonal types and sites of bacterial isolation [20]. A previous study conducted by [25] revealed similar findings after varying $\mathrm{pH}$ and $\mathrm{Fe}^{3+}$ concentration in relation to the site of bacterial isolation. They affirmed that biofilm formation among Streptococcus pneumoniae serotype 3 clinical isolates was determined by the site of isolation and is affected by changes in $\mathrm{pH}$ and $\mathrm{Fe}^{3+}$ concentration.

The presence of biofilm-producing bacteria in the urine has implications on the prognosis of a possible urinary tract infection. Such infection can lead to pyelonephritis [26] and/or chronic bacterial prostatitis. Diagnosis of the latter is quite difficult because the bacteria cannot be detected in the prostatic secretion or urine of patients [27] (possibly because they exist as biofilms and not in planktonic form). Catheterassociated urinary tract infections (CAUTIs) are also associated with biofilm-forming bacteria, where most infections have been observed to be monomicrobial [28]. Treatment of such diseases can pose a therapeutic challenge due to the ability of the pathogens to exist as biofilm, with marked resistance to antimicrobial drugs.

Analysis of acquired resistance profile of biofilmproducing isolates in this study revealed that a significant majority of the isolates were multidrug resistant (MDR) and extensively drug resistant (XDR), while the rest were Pandrug resistant (PDR). Biofilm-producing bacteria have been associated with a high rate of multiple drug resistance. That is why biofilm-based infections tend to be refractory, exceptionally difficult to treat and can lead to chronic infections with fatal consequences. This becomes more worrisome when such an infection occurs in immunocompromised individuals.

The scourge of multiple drug resistance is quite prevalent among a wide spectrum of pathogenic bacteria. Such multiple resistance is usually acquired and can be attributed, in most cases, to horizontal transfer of multiple resistance genes carried on plasmids. However, another factor that can contribute to such an extensive resistance capacity is the ability to form biofilm, as results of this study has demonstrated. So many explanations have been given with regards to why biofilm producing bacteria are more resistant than planktonic strains [9], [10], [11], [12], [13], [14]. However, further studies is required to examine the biofilm physiology with a view to unearthing the mechanisms 
involved. Understanding such processes can serve as a guide towards drug design by identifying possible target site(s) for antimicrobial activity.

However, a limitation of this study is in the fact that biofilm formation was studied on a single-specie basis. In most cases, biofilm is a multispecie community where interactions can modulate the overall antimicrobial tolerance level. Such interactions are relevant in both biofilm and planktonic infections given the polymicrobial nature of most infections.

\section{CONCLUSION}

We found a high biofilm formation rate among clinical bacterial isolates. Staphylococcus aureus and Pseudomonas aeruginosa were observed to be the predominant biofilm producers. Isolates derived from Urine samples were the most significant biofilm producers. We also observed that biofilmproducing isolates have a highly reduced/non-susceptibility to multiple antimicrobial drugs. Extreme forms of multiple drug resistance (XDR and PDR) were found predominantly among biofilm producing strains of a bacterial specie.

\section{ACKNOWLEDGEMENTS}

We acknowledge the support and permission granted to us by the management of the University of Maiduguri Teaching Hospital, Nigeria, for conducting this study.

\section{CONFLICT OF INTEREST}

We declare that there is no competing interest.

\section{REFERENCES}

1. L. Hall-Stoodley, W. J. Costerton, and P. Stoodley, "Bacterial biofilms: from the natural environment to infectious diseases," Nature Reviews Microbiology vol. 2, pp. 95-108, February 2004 https://doi.org/10.1038/nrmicro821.

2. G. Peters, R. Locci, and G. Pulverer, "Microbial colonization of prosthetic devices. II. Scanning electron microscopy of naturally infected intravenous catheters," Zentralb. Bacteriol. Mikrobiol. Hyg, vol. 173, no. 5, pp. 293-299. May 1981 https://pubmed.ncbi.nlm.nih.gov/6792814/.

3. M. D. Rodney, "Biofilms and device-associated infections," Emerg. Infect. Dis, vol. 7, no. 2, pp. 277-281, April 2001. https://pubmed.ncbi. nlm.nih.gov/11294723/.

4. C. Koch, and N. Hoiby, "Pathogenesis of cystic fibrosis," Lancet, vol. 341, pp. 1065-1069, April 1993.https://www.sciencedirect.com/science/article/abs/pii/01406736 9392422P

5. P. K. Singh, A. L. Schaefer, M. R. Parsek, T. O. Moninger, M. J. Welsh, and E. P. Greenberg, "Quorum-sensing signals indicate that cystic fibrosis lungs are infected with bacterial biofilms", Nature, vol. 407, pp. 762-764, October 2000. doi: 10.1038/35037627. https://pubmed.ncbi.nlm.nih. gov/11048725/.

6. J. W. Costerton, J. Lam, K. Lam, and R. Chan, "The role of the microcolony mode of growth in the pathogenesis of Pseudomonas aeruginosa infections", Rev. Infect. Dis. vol. 5, pp. S867-S873, December 1983. doi: 10.1093/clinids/5 supplement_5. s867. https://pubmed.ncbi.nlm.nih .gov/6419312/

7. J. Lam, R. Chan, K. Lam, and J. W. Costerton, "Production of mucoid microcolonies by Pseudomonas aeruginosa within infected lungs in cystic fibrosis", Infect Immun, vol. 28, pp. 546-556, May 1980 http://iai.asm.org/

8. M. M. Ibrahim, I. Adam, U. M. Garba, and S. Shuaibu. "Multiple-drug
Resistance among Biofilm-producing Phenotypes of Nosocomial Escherichia coli," Microbiology Research Journal International, vol 25, no. 5, pp. 1-8, December 2018 https://doi.org/10.9734/MRJI/2018/45696.

9. M. Sugano, H. Morisaki, Y. Negishi, Y. Endo-Takahashi, H. Kuwata, T. Miyazaki, et al. "Potential effect of cationic liposomes on interactions with oral bacterial cells and biofilms," J. Liposome Res, vol. 26, no. 2, 156-162, July 2015 doi.org/10.3109/08982104.2015.1063648.

10. J. N. Ander, J. Zahller, and P.S. Stewart, "Role of nutrient limitation and stationary-phase existence in Klebsiella pneumoniae biofilm resistance to Ampicillin and Ciprofloxacin," Antimicrob. Agents Chemother, vol 47, pp. 1251-1256, April 2003.

11. C. A. Fux, S. Wilson, and P. Stoodley, "Detachment characteristics and oxacillin resistance of Staphyloccocus aureus biofilm emboli in an in vitro catheter infection model," J Bacteriol, vol. 186, no. 14, pp. 44864491, July 2004. doi: 10.1128/JB.186.14.4486-4491.2004.

12. S. J. Liaw, Y. L. Lee, and P. R. Hsueh, "Multidrug resistance in clinical isolates of Stenotrophomonas maltophilia: roles of integrons, efflux pumps, phosphoglucomutase (SpgM), and melanin and biofilm formation," Int. J. Antimicrob. Agents, vol. 35, no. 2, pp. 126-130, November 2010. doi: 10.1016/j.ijantimicag.2009.09.015.

13. O. Gefen, B. Chekol, J. Strahilevitz, and N. Q. Balaban, "TDtest: easy detection of bacterial tolerance and persistence in clinical isolates by a modified disk-diffusion assay," Sci. Rep, vol. 7, pp. 41284, February 2017. https://www.nature.com /articles /srep41284.

14. S. Singh, S. K. Singh, I. Chowdhury, and R. Singh, "Understanding the Mechanism of Bacterial Biofilms Resistance to Antimicrobial Agents,' Open Microbiol J, vol. 11:53-62. April 2017. doi 10.2174/1874285801711010053.

15. M. Cheesebrough, District Laboratory Practice for Tropical Countries, $2^{\text {nd }}$ ed, Cambridge University Press, U.K.: 2006, pp. 71-124.

16. J. Freeman, F. R. Falkiner, and C. T. Keane, "New method for detecting slime production by coagulase negative staphylococci," J Clin Pathol, vol. 42, pp. 872-4, August 1989. doi: 10.1136/jcp.42.8.872.

17. CLSI. Performance Standards for Antimicrobial Susceptibility Testing. 27th ed. CLSI supplement M100. Wayne, PA: Clinical and Laboratory Standards Institute; 2017.

18. A. P. Magiorakos, A. Srinivasan, R. B. Carey, Y. Carmeli, M. E. Falagas, C. G. Giske, et al. "Multidrug-resistant, extensively drugresistant and pandrug-resistant bacteria: an international expert proposal for interim standard definitions for acquired resistance," Clinical microbiology and infection, vol. 18, no. 3, pp. 268-281, March 2012. https://doi.org/10.1111/j.1469-0691.2011.03570.x.

19. M. Gashaw, M. Berhane, S. Bekele, G. Kibru, L. Teshager, Y. Yilma, et al. "Emergence of high drug resistant bacterial isolates from patients with health care associated infections at Jimma University medical center: a cross sectional study," Antimicrobial Resistance \& Infection Control, vol. 7, no. 1, pp. 138, November 2018 https://doi.org/10.1186/s13756-018-0431-0.

20. C. J. Sanchez, K. Mende, M. L. Beckius, et al. "Biofilm formation by clinical isolates and the implications in chronic infections," BMC Infect Dis, vol. 13, pp. 47, January 2013. https://doi.org/10.1186/1471-2334$13-47$.

21. M. Hussain, M. H. Wilcox, and P. J. White, "The slime of coagulasenegative staphylococci: biochemistry and relation to adherence," FEMS Microbiol Rev, vol. 10, pp. 191-207, April 1993. doi: 10.1111/j.1574-6968.1993.tb05867.x

22. B. H. Ziran, “Osteomyelitis," J Trauma, vol. 62, pp. 59-60, June 2007 PMID:17556977; doi:10.1097/TA.0b013e318065abbd.

23. N. K. Archer, J. Mark, J. Mazaitis, W. Costerton, G. Jeff, E. Shirtliff, et al. "Staphylococcus aureus biofilms. Properties, regulation and roles in human disease", Virulence, vol. 2, no. 5, pp. 445-459, October 2011. http://dx.doi.org/10.4161/viru.2.5 .17724.

24. B. M. Peters, M. A. Jabra-Rizk, M. A. Scheper, J. G. Leid, J. W Costerton, and M. E. Shirtliff, "Microbial interactions and differential protein expression in Staphylococcus aureus-Candida albicans dualspecies biofilms," FEMS Immunol Med Microbiol, vol. 59, pp. 493 503, August 2011. doi: 10.1111/j.1574-695X.2010.00710.x.

25. C. Trappetti, E. van der Maten, Z. Amin, A. J. Potter, A. Y. Chen, P M. van Mourik, et al. "Site of isolation determines biofilm formation and virulence phenotypes of Streptococcus pneumoniae serotype 3 clinical isolates," Infection and immunity, vol. 81, no. 2, pp. 505-513, February 2013. doi: 10.1128/IAI.01033-12. 
26. J. C. Nickel, I. Ruseska, J. B. Wright, and J. W. Costerton, "Tobramycin resistance of Pseudomonas aeruginosa cells growing as a biofilm on urinary catheter material," Antimicrobial Agents and Chemotherapy, vol. 27, no. 4, pp. 619-624, April 1985.

27. Choong S. and Whitfield, H. "Biofilms and their role in infections in urology," BJU International, vol. 86, no. 8, pp. 935-941, November 2000. doi: 10.1046/j.1464-410x.2000.00949.x.

28. Tambyah, P. A. "Catheter-associated urinary tract infections: diagnosis and prophylaxis," International Journal of Antimicrobial Agents, vol. 24, supplement 1, pp. S44-S48, September 2004. doi: 10.1016/j.ijantimicag.2004.02.008. 